\title{
ВИВЧЕННЯ ВПЛИВУ ДОПОМІЖНИХ РЕЧОВИН НА ФАРМАКО-ТЕХНОЛОГІЧНІ ВЛАСТИВОСТІ ТАБЛЕТОК СУХОГО ПОРОШКУ БІОМАСИ FLAMMULINA VELUTIPES
}

\author{
() Т. А. Буткевич ${ }^{1}$, М. Л. Сятиня 1 , В. П. Попович ${ }^{2}$ \\ Національний медичний університет імені О. О. Богомольця ${ }^{1}$, Київ \\ TOB «ВТФ «ЕКMІ» 2, Українка \\ but-t@ukr.net
}

\begin{abstract}
Мета роботи. Вивчити вплив чотирьох груп допоміжних речовин (наповнювачі, розпушувачі, змащувальні та ковзні, зв'язуючі) на фрармако-технологічні властивості таблеток сухого порошку біомаси Flammulina velutipes. Матеріали і методи. Дослідження впливу допоміжних речовин (ДР) на такі показники, як зовнішній вигляд, однорідність маси, стійкість до роздавлювання, стираність та розпадання таблеток проводили відповідно до вимог ДФУ 2 видання. Вивчення чотирьох груп ДР здійснювали за допомогою математичного планування експерименту. Результати й обговорення. На підставі множинних порівнянь рівнів вивчених фракторів зроблено висновки про вплив ДР на показники якості таблеток сухого порошку біомаси F. velutipes. При використанні будь- якого із представників груп ДР одержували близькі результати впливу на однорідність маси таблеток. Задовільні результати стираності таблеток одержано у 13 серіях дослідів, 3 них 5 мали середній показник менше 0,5\%. Спресовані таблетки сухого порошку біомаси F. velutipes мали різні показники міцності, лише у 9 серіях дослідів показник був вищим 50 Н. При вивченні впливу ДР на розпадання таблеток виявили 7 незадовільних серій препарату.

Висновки. Встановлено вплив чотирьох груп ДР на такі фрармако-технологічні характеристики таблеток сухого порошку біомаси F. velutipes, як зовнішній вигляд, однорідність маси, стійкість до роздавлювання та розпадання. Відібрано оптимальні представники досліджуваних груп ДР (цукор білий подрібнений, глина біла, кислота стеаринова, 2 \% крохмальний клейстер) для отримання таблеток сухого порошку біомаси F. velutipes методом вологого гранулювання.
\end{abstract}

Ключові слова: біомаса; Flammulina velutipes; таблетки; допоміжні речовини; фрармако-технологічні властивості; математичне планування експерименту.

Вступ. Для медичного застосування на сьогодні в Україні серед препаратів природного походження засоби на основі їстівних та лікарських грибів займають незначну питому частку. У сучасній срармації переважає розробка та виробництво препаратів з рослинної сировини [1]. Однак, як свідчить досвід багатьох країн (особливо Східної Азії), лікарські макроміцети заслуговують особливої уваги, адже є продуцентами численної групи біологічно активних речовин. Одним із актуальних завдань сучасної фрармацевтичної технології залишається питання реалізації вітчизняного наукового потенціалу у сорері виробництва лікарських та лікувально-профрілактичних засобів на основі грибів.

Попередніми дослідженнями встановлено, що для отримання твердої лікарської форми у вигляді таблеток необхідне покращення деяких фармако-технологічних показників сухого порошку біомаси (СПБ) [2]. Під час дослідження використовували методи вологого гранулювання та прямого пресування таблеток.

Отже, метою цієї роботи було вивчення впливу 4 груп ДР (наповнювачі, розпушувачі, змащувальні та ковзні, зв'язуючі) на фрармако-технологічні властивості таблеток СПБ Flammulina (F.) velutipes.

Матеріали і методи. Об'єктом дослідження були таблетки СПБ F. velutipes, отримані методами прямого пресування та вологого гранулювання. Маса для таблетування містила 80 \% біомаси гриба та 20 \% ДР. СПБ отримано культивуванням на середовищі водної суспензії $\mathrm{CO}_{2}$-шроту амаранту (дослідне виробництво Державної установи «Інститут харчової біотехнології та геноміки Національної академії наук України» (м. Київ) та ПВКФ «Ганоль» (м. Кропивницький)) [3] 3 подальшим висушуванням у вакуумній ліофільній сушарці Cryodos-500 (Terrasa, Іспанія) та подрібненням на лабораторному зерновому млині л3М-1 (швидкість обертання валу електродвигуна 16500 об./хв) протягом 30 секунд [2]. ДР було об'єднано у групи відповідно до здатності змінювати властивості порошкових сумішей - наповнювачі, розпушуючі, змащувальні та ковзні, зв'язуючі (табл. 1).

Під час приготування суміші компонентів без додавання зв'язуючих речовин дотримувались наступної послідовності дій: відважували СПБ F. velutipes,

ISSN 2312-0967. Pharmaceutical review. 2017. № 3 
Фармацевтична технологія, біофармація, гомеопатія Pharmaceutical technology, biopharmacy, homeopathy

Таблиця 1. Допоміжні речовини, які вивчали при розробці таблеток СПБ F. velutipes

\begin{tabular}{|c|c|}
\hline Фактори & Рівні фракторів \\
\hline А - наповнювачі & $\begin{array}{l}\mathrm{a}_{1}-\text { магнію карбонат основний } \\
\mathrm{a}_{2}-\text { цукор білий подрібнений } \\
\mathrm{a}_{3}-\text { мікрокристалічна целюлоза (МКЦ) } 102 \\
\mathrm{a}_{4}-\text { кальцію карбонат }\end{array}$ \\
\hline В - розпушуючі речовини & $\begin{array}{l}\mathrm{b}_{1}-\text { крохмаль картопляний висушений } \\
\mathrm{b}_{2}-\text { глина біла } \\
\mathrm{b}_{3}-\text { полівінілпіролідон (ПВП) } \\
\mathrm{b}_{4}-\text { крохмаль картопляний висушений:аеросил (1:1) }\end{array}$ \\
\hline С - змащувальні та ковзні речовини & $\begin{array}{l}\mathrm{c}_{1}-\text { тальк } \\
\mathrm{c}_{2}-\text { кислота стеаринова } \\
\mathrm{c}_{3}-\text { магнію стеарат } \\
\mathrm{c}_{4}-\text { поліетиленгліколь (ПЕГ) } 4000 \text { подрібнений }\end{array}$ \\
\hline D - зв'язуючі речовини & $\begin{array}{l}\mathrm{d}_{1}-\text { без зв'язуючих речовин } \\
\mathrm{d}_{2}-20 \% \text { розчин ПвП } \\
\mathrm{d}_{3}-5 \% \text { крохмальний клейстер } \\
\mathrm{d}_{4}-2 \% \text { крохмальний клейстер }\end{array}$ \\
\hline
\end{tabular}

потім ДР - наповнювачі (речовини з групи фрактора А), розпушувачі (речовини з групи фрактора В), змащувальні та ковзні (речовини з групи фрактора С) та ретельно перемішували на кожній стадії. Для отримання грануляту порядок дій був наступним: СПБ F. velutipes змішували із наповнювачами та розпушуючими речовинами, додавали розчин зв'язуючих речовин (речовини з групи фрактора D) у необхідній кількості для одержання пластичної маси. Вологу масу протирали через сито з розміром отворів 3 мм та висушували за допомогою сушарки МИЗ-МА при температурі не вище $40{ }^{\circ} \mathrm{C}$. Одержану суху масу протирали через сито з розміром отворів 1 мм та опудрювали змащувальними та ковзними речовинами [4].

Вивчали вплив ДР на такі показники, як зовнішній вигляд, однорідність маси (ДФУ 2.9.5., с. 409), стійкість до роздавлювання (ДФУ 2.9.8., с. 411), стираність (ДФУ 2.9.7., с. 410) та розпадання (ДФУ 2.9.1., с. 395) [5]. Для проведення експерименту використовували метод математичного планування, а саме вивчення 4 якісних фракторів за допомогою 4х4 греколатинського квадрату [6]. Досліди реалізовано у двох повтореннях (табл. 2).

Всі дослідження були проведені на базі компанії HВО «Екомед». Пресування таблеток СПБ F. velutipes здійснювали на однопуансонній таблетковій машині Single Punch Tablet Press TDP-5 (MINHUA Pharmaceutical Machinery CO, Ltd., China). Стійкість до роздавлювання визначали за допомогою ҮPJ200A Tablet hardness tester, стираність таблеток Tablet friability tester CS-2, розпадання - Disintegration tester BJ-2 (MINHUA Pharmaceutical Machinery CO, Ltd., China). Одержані таблетки різних серій відрізнялися за зовнішнім виглядом та показниками якості, а саме деякі з них мали неоднорідну поверхню, розпадалися після проведення визначень тощо.

Результати й обговорення. Результати експериментальних досліджень підлягали дисперсійному аналізу за схемою, що наведена в роботі [6].

На підставі множинних порівнянь рівнів вивчених фракторів за допомогою критерію Дункана було зроблено висновки про вплив ДР на показники якості таблеток СПБ F. velutipes.

Встановлено, що ДР речовини з групи наповнювачів за впливом на показники зовнішнього вигляду таблеток $\left(\mathrm{y}_{1}\right)$ можна проранжувати наступним чином: $\mathrm{a}_{2}$ $=a_{4}>a_{1}>a_{3}$ (цукор білий подрібнений $(3,4)=$ кальцію карбонат $(3,875)>$ магнію карбонат основний $(2,75)>$ МКЦ 102 (1,375). Рівними також були наступні значення рівнів фрактора С: магнію стеарат $(3,5)=$ тальк $(3,37)=$ кислота стеаринова $(2,75)$, їх вплив переважав результати ПЕГ 4000 подрібненого $(2,375)$. Тобто ранжований ряд переваг для зразків змащувальних та ковзних речовин має наступний вигляд: $\mathrm{c}_{3}=\mathrm{c}_{1}=\mathrm{c}_{2}>\mathrm{C}_{4}$. Оскільки для фракторів B і D емпіричне значення $\mathrm{F}$ критерію менше критичного - розпушуючі та зв'язуючі речовини однаковою мірою впливають на процес пресування таблеток і між рівнями вказаних фракторів немає різниці.

Одним із показників якості таблеток є однорідність маси $\left(\mathrm{y}_{2}\right)$. При використанні будь якого із представників груп ДР одержували близькі результати. Кращі показники отримували при використанні магнію карбонату основного $( \pm 2,14 \%)$, цукру білого подрібненого $( \pm 2,22 \%)$ та кальцію карбонату ( $\pm 2,67 \%)$. Найбільше відхилення від середнього показало використання МКЦ 102 ( $\pm 3,66 \%)$ у якості наповнювача. Найвищими $€$ результати впливу на однорідність маси таблеток таких розпушуючих речовин, як крохмаль карто-

ISSN 2312-0967. Фармацевтичний часопис. 2017. № 3 
Фармацевтична технологія, біофармація, гомеопатія Pharmaceutical technology, biopharmacy, homeopathy

Таблиця 2. Матриця планування експерименту на основі 4х4 греко-латинського квадрату та результати дослідження таблеток СПБ F. velutipes

\begin{tabular}{|c|c|c|c|c|c|c|c|c|c|c|c|c|c|c|}
\hline № & $\mathbf{A}$ & $\mathbf{B}$ & $\mathbf{C}$ & $\mathbf{D}$ & $\mathbf{y}_{\mathbf{1}}$ & $\mathbf{y}_{\mathbf{1}}{ }^{\prime}$ & $\mathbf{y}_{\mathbf{2}}$ & $\mathbf{y}_{\mathbf{2}}{ }^{\prime}$ & $\mathbf{y}_{\mathbf{3}}$ & $\mathbf{y}_{\mathbf{3}}{ }^{\prime}$ & $\mathbf{y}_{\mathbf{4}}$ & $\mathbf{y}_{\mathbf{4}}{ }^{\prime}$ & $\mathbf{y}_{\mathbf{5}}$ & $\mathbf{y}_{\mathbf{5}}{ }^{\prime}$ \\
\hline $\mathbf{1}$ & $\mathrm{a}_{1}$ & $\mathrm{~b}_{1}$ & $\mathrm{c}_{1}$ & $\mathrm{~d}_{1}$ & 3 & 4 & 2,64 & 2,91 & 12,5 & 11 & 0,67 & 0,68 & 12,83 & 12,5 \\
\hline $\mathbf{2}$ & $\mathrm{a}_{1}$ & $\mathrm{~b}_{2}$ & $\mathrm{c}_{2}$ & $\mathrm{~d}_{3}$ & 3 & 2 & 2,23 & 2,2 & 56,5 & 55,5 & 1,14 & 1,07 & 13,5 & 13,67 \\
\hline $\mathbf{3}$ & $\mathrm{a}_{1}$ & $\mathrm{~b}_{3}$ & $\mathrm{c}_{4}$ & $\mathrm{~d}_{4}$ & 2 & 2 & 1,88 & 1,89 & 63,5 & 64,5 & 0,93 & 0,94 & 15,83 & 15,67 \\
\hline $\mathbf{4}$ & $\mathrm{a}_{1}$ & $\mathrm{~b}_{4}$ & $\mathrm{c}_{3}$ & $\mathrm{~d}_{2}$ & 3 & 3 & 1,69 & 1,69 & 40,5 & 39,5 & 0,82 & 0,84 & 20 & 19,83 \\
\hline $\mathbf{5}$ & $\mathrm{a}_{2}$ & $\mathrm{~b}_{1}$ & $\mathrm{c}_{2}$ & $\mathrm{~d}_{2}$ & 3 & 4 & 1,55 & 1,74 & 61,5 & 62,5 & 0,23 & 0,25 & 13,17 & 13 \\
\hline $\mathbf{6}$ & $\mathrm{a}_{2}$ & $\mathrm{~b}_{2}$ & $\mathrm{c}_{1}$ & $\mathrm{~d}_{4}$ & 5 & 5 & 1,15 & 1,13 & 92,5 & 93 & 0,17 & 0,18 & 11,5 & 11,33 \\
\hline $\mathbf{7}$ & $\mathrm{a}_{2}$ & $\mathrm{~b}_{3}$ & $\mathrm{c}_{3}$ & $\mathrm{~d}_{3}$ & 4 & 4 & 4,02 & 3,96 & 68 & 67,5 & 0,43 & 0,41 & 13,5 & 13,33 \\
\hline $\mathbf{8}$ & $\mathrm{a}_{2}$ & $\mathrm{~b}_{4}$ & $\mathrm{c}_{4}$ & $\mathrm{~d}_{1}$ & 4 & 3 & 2,09 & 2,13 & 40 & 38,5 & 0,58 & 0,61 & 17,5 & 17,67 \\
\hline $\mathbf{9}$ & $\mathrm{a}_{3}$ & $\mathrm{~b}_{1}$ & $\mathrm{c}_{3}$ & $\mathrm{~d}_{3}$ & 2 & 2 & 3,04 & 3,01 & 51 & 50 & 0,97 & 0,99 & 17,17 & 17 \\
\hline $\mathbf{1 0}$ & $\mathrm{a}_{3}$ & $\mathrm{~b}_{2}$ & $\mathrm{c}_{4}$ & $\mathrm{~d}_{1}$ & 1 & 1 & 3,95 & 4,09 & 10 & 10 & 10,28 & 10,46 & 0,5 & 0,33 \\
\hline $\mathbf{1 1}$ & $\mathrm{a}_{3}$ & $\mathrm{~b}_{3}$ & $\mathrm{c}_{1}$ & $\mathrm{~d}_{2}$ & 1 & 1 & 4,21 & 4,24 & 10 & 10 & 9,12 & 9,26 & 0,33 & 0,17 \\
\hline $\mathbf{1 2}$ & $\mathrm{a}_{3}$ & $\mathrm{~b}_{4}$ & $\mathrm{c}_{2}$ & $\mathrm{~d}_{4}$ & 2 & 1 & 3,38 & 3,37 & 77 & 78 & 0,99 & 0,97 & 15,77 & 15,83 \\
\hline $\mathbf{1 3}$ & $\mathrm{a}_{4}$ & $\mathrm{~b}_{1}$ & $\mathrm{c}_{4}$ & $\mathrm{~d}_{4}$ & 3 & 3 & 1,97 & 2,07 & 60,7 & 59,5 & 0,41 & 0,43 & 14,83 & 15 \\
\hline $\mathbf{1 4}$ & $\mathrm{a}_{4}$ & $\mathrm{~b}_{2}$ & $\mathrm{c}_{3}$ & $\mathrm{~d}_{2}$ & 5 & 5 & 2,48 & 2,51 & 78,5 & 78,5 & 0,46 & 0,47 & 13 & 13,17 \\
\hline $\mathbf{1 5}$ & $\mathrm{a}_{4}$ & $\mathrm{~b}_{3}$ & $\mathrm{c}_{2}$ & $\mathrm{~d}_{1}$ & 3 & 4 & 2,24 & 2,19 & 39 & 38,5 & 0,58 & 0,6 & 13,5 & 13 \\
\hline $\mathbf{1 6}$ & $\mathrm{a}_{4}$ & $\mathrm{~b}_{4}$ & $\mathrm{c}_{1}$ & $\mathrm{~d}_{3}$ & 4 & 4 & 3,99 & 3,94 & 10,5 & 12,5 & 0,65 & 0,62 & 16,33 & 16 \\
\hline
\end{tabular}

Примітки: $y_{1}$ та y $_{1}{ }^{-}$- зовнішній вигляд таблеток першої і другої серії відповідно, бали; у ${ }_{2}$ та у $_{2}{ }^{-}$- однорідність маси

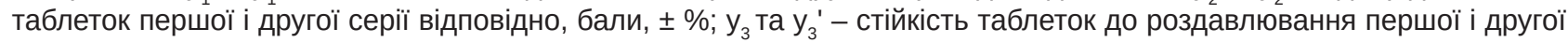

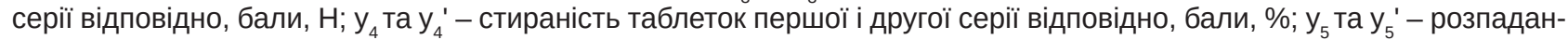
ня таблеток першої і другої серії відповідно, бали, хв.

пляний висушений $( \pm 2,37 \%)$ та глина біла $( \pm 2,47 \%)$. Кислота стеаринова ( $\pm 2,36 \%)$ та ПЕГ 4000 подрібнений (士 2,51\%) мали найкращі показники серед представників фрактора С. Ранжовані середні показники для фрактора D виглядають наступним чином: 2\% крохмальний клейстер - \pm 2,11 \%, $20 \%$ розчин ПВП - $\pm 2,51 \%$, відсутність зв'язуючих речовин - $\pm 2,78 \%$ та $5 \%$ крохмальний клейстер - \pm 3,30\%.

Спресовані таблетки СПБ F. velutipes мали різні показники міцності, лише у 9 серіях дослідів із 16 показник був вищим 50 Н. Деякі з одержаних зразків руйнувалися під час проведення випробувань. Найміцнішими виявилися таблетки, що містили цукор білий подрібнений $(65,44$ Н), глину білу $(59,31$ Н), магнію стеарат та кислоту стеаринову $(59,19$ Н та 58,56 H). Незадовільні показники міцності одержали при використанні МКЦ 102 (37 Н), суміші крохмалю картопляного висушеного й аеросилу $(42,06$ Н) та тальку (31,5 Н). Найбільший вплив на показник стійкості таблеток до роздавлювання мали зв'язуючі речовини. Ранжований ряд переваг цієї групи можна представити так: $\mathrm{d}_{4}>\mathrm{d}_{1}=\mathrm{d}_{3}=\mathrm{d}_{2}$. Використання $2 \%$ крохмального клейстеру дозволяє одержати таблетки із середнім показником міцності 73,59 Н.

Задовільні результати стираності таблеток (не більше $1 \%$ ) одержано у 13 серіях дослідів, 3 них 5 мали середній показник менше 0,5 \%. Найкращі показники представників фрактора А одержано при ви- користанні цукру білого подрібненого (0,36 \%), незадовільними виявилися результати зразків із МКЦ 102 (5,38 \%). Щодо розпушуючих речовин, то при введенні до складу таблеток крохмалю картопляного висушеного отримали найкращі результати стираності 0,58 \%. Близькі задовільні результати впливу мали рівні фрактора $\mathrm{C}-\mathrm{C}_{3}$ (магнію стеарат) та $\mathrm{C}_{2}$ (кислота стеаринова) - 0,67 та 0,73 \% відповідно. При використанні зв'язуючих речовин, лише $\mathrm{d}_{3}-5 \%$ крохмальний клейстер $(0,79 \%)$ та $\mathrm{d}_{4}-2 \%$ крохмальний клейстер (0,63 \%) забезпечили одержання задовільних показників.

При вивченні впливу ДР на розпадання таблеток виявили 7 незадовільних серій препарату. Найшвидше розпадалися таблетки, що містили МКЦ 102 як наповнювач (8,4 хв). Задовільними також були результати зразків із цукром білим подрібненим (13,9 хв) та кальцію карбонатом (14,3 хв). При порівнянні ранжованих середніх значень результатів досліджень, розпушуючі речовини можна розмістити у такій послідовності: глина біла (9,6 хв) > ПВП (10,7 хв) $>$ крохмаль картопляний висушений $(14,4$ хв) > крохмаль картопляний висушений : аеросил 1:1 (17,4 хв). За ступенем впливу на процес розпадання досліджуваних таблеток змащувальні та ковзні речовини можна розмістити наступним чином: тальк $(10,1$ хв) > ПЕГ 4000 подрібнений (12,2 хв) > кислота стеаринова $(13,9$ хв) > магнію стеарат (15,9 хв). Відсутність

ISSN 2312-0967. Pharmaceutical review. 2017. № 3 
Фармацевтична технологія, біофармація, гомеопатія Pharmaceutical technology, biopharmacy, homeopathy

зв'язуючих речовин (фрактор $\mathrm{d}_{1}$ ) та додавання $20 \%$ розчину ПВП (фактор $\mathrm{d}_{2}$ ) дозволяло отримати зразки із середніми ранжованими показниками 10,98 та 11,58 хв відповідно. Незадовільними виявилися середні експериментальні результати зразків, що містили 5 \% крохмальний клейстер (15,06 хв) як зв'язуючу речовину.

Висновки. За допомогою математичного планування експерименту встановлено вплив чотирьох груп ДР (наповнювачі, розпушуючі, змащувальні та ковзні, зв'язуючі) на такі фрармако-технологічні характеристики таблеток СПБ F. velutipes, як зовнішній вигляд, однорідність маси, стійкість до роздавлювання та розпадання. Відібрано оптимальні представники досліджуваних груп ДР (цукор білий подрібнений, глина біла, кислота стеаринова, 2\% крохмальний клейстер) для отримання таблеток СПБ F. velutipes методом вологого гранулювання.

\title{
ИЗУЧЕНИЕ ВЛИЯНИЯ ВСПОМОГАТЕЛЬНЫХ ВЕЩЕСТВ НА ФАРМАКО-ТЕХНОЛОГИЧЕСКИЕ СВОЙСТВА ТАБЛЕТОК СУХОГО ПОРОШКА БИОМАССЫ FLAMMULINA VELUTIPES
}

\author{
Т. А. Буткевич ${ }^{1}$ М. Л. Сятыня 1 В. П. Попович² \\ Национальный медицинский университет имени А. А. Богомольца ${ }^{1}$, Киев \\ ООО «ПТФ «ЭКМИ» ${ }^{2}$, Украинка \\ but-t@ukr.net
}

Цель работы. Изучить влияние четырех групп вспомогательных веществ (наполнители, разрыхлители, смазывающие и скользящие, связывающие) на фрармако-технологические свойства таблеток сухого порошка биомассы Flammulina velutipes.

Материалы и методы. Исследование влияния вспомогательных веществ (BВ) на такие показатели как внешний вид, однородность массы, устойчивость к раздавливанию, истираемость и распадаемость таблеток проводили в соответствии с требованиями ГФУ 2 издания. Изучение влияния четырех групп ВВ осуществляли с помощью метода математического планирования эксперимента.

Результаты и обсуждение. На основании множественных сравнений уровней изученных фракторов были сделаны выводы о влиянии ВВ на показатели качества таблеток сухого порошка биомассы F. velutipes. При использовании любого из представителей групп ВВ получали близкие результаты воздействия на однородность массы таблеток. Удовлетворительные результаты истираемости таблеток получено в 13 сериях опытов, из них 5 имели средний показатель меньше 0,5 \%. Спрессованные таблетки сухого порошка биомассы F. velutipes имели различные показатели прочности, только в 9 сериях опытов показатель был выше $50 \mathrm{H}$. При изучении влияния ВВ на распадаемость таблеток обнаружили 7 неудовлетворительных серий препарата

Выводы. Установлено влияние четырех групп ВВ на такие фрармако-технологические характеристики таблеток сухого порошка биомассы F. velutipes, как внешний вид, однородность массы, устойчивость к раздавливанию и распадаемость. Отобраны оптимальные представители исследуемых групп ВВ (сахар белый измельченный, глина белая, стеариновая кислота, $2 \%$ крахмальный клейстер) для получения таблеток сухого порошка биомассы $F$. velutipes методом влажного гранулирования.

Ключевые слова: биомасcа; Flammulina velutipes; таблетки; вспомогательные вещества; фрармако-технологические свойства; математическое планирование эксперимента.

\section{STUDY OF THE EXCIPIENTS INFLUENCE ON PHARMACO-TECHNOLOGICAL PROPERTIES OF FLAMMULINA VELUTIPES BIOMASS DRY POWDER TABLETS}

\author{
T. A. Butkevych ${ }^{1}$, M. L. Syatynya $^{1}$, V. P. Popovych ${ }^{2}$ \\ O. Bohomolets National Medical University ${ }^{1}$, Kyiv \\ «PTF «Acme» Co. Ltd, Ukrainka \\ e-mail: but-t@ukr.net
}

The aim of the work. Studying the impact of four groups of excipients (fillers, disintegrants, lubricants and glidants, binders) on the pharmaco-technological properties of Flammulina velutipes biomass dry powder tablets.

Materials and Methods. Research of the impact of excipients on such parameters as surface quality, uniformity of weight, resistance to crushing, friability and disintegration of tablets was carried out in accordance to the requirements of State Pharmacopoeia of Ukraine 2nd edition using the method of mathematical experiment planning.

ISSN 2312-0967. Фармацевтичний часопис. 2017. № 3 
Results and Discussion. Conclusions about the impact of excipients on F. velutipes biomass dry powder tablets quality indicators were made based on comparisons of multiple levels of studied factors. When using any of representatives of the groups of excipients we obtained similar results of impact on tablet weight uniformity. Satisfactory results of tablet friability were obtained in 13 series of experiments, 5 of them had an average of less than $0.5 \%$. Compressed $F$. velutipes biomass dry powder tablets had different strength values, only in 9 series of experiments the index was above $50 \mathrm{~N}$. 7 unsatisfactory series of the preparation were found during the study of the effect of excipients on the disintegration of tablets.

Conclusions. The influence of four groups of the excipients on such pharmaco-technological properties of Flammulina velutipes biomass dry powder tablets as surface quality, uniformity of weight, resistance to crushing, friability and disintegration was found. Optimal representatives of the studied groups of excipients (powdered sugar, kaolin, stearic acid, $2 \%$ starch paste) were selected for the production of Flammulina velutipes biomass dry powder tablets by the wet granulation method.

Key words: biomass; Flammulina velutipes; tablets; excipients; pharmaco-technological properties; mathematical experiment planning.

\section{Список літератури}

1. Царик Н. П. Культивовані гриби в грибівництві та медицині. Один з нарисів ситуації в Україні / Н. П. Царик // Харчова наука і технологія. - № 4(25). - 2013. - С. 104-107.

2. Буткевич Т. А. Визначення фрізичних та фрармакотехнологічних властивостей сухого порошку біомаси Flammulina velutipes/ Т. А. Буткевич, М. Л. Сятиня, В. П. Попович // Фармацевт. часоп. - № 2. - 2016. - С.11-15. 3. Пат. 117165 Україна, МПК (2006): А61K 31/00, A61K 36/00, A01G 1/04 (2006.01). Біологічно активна субстанція 3 імуномодулюючою активністю / Сятиня М. Л., Попович В. П., Буткевич Т. А., Бісько Н. А., Круподьорова Т. А., Козіко Н. О.; заявник і патентовл. Національний медичний університет імені О.О. Богомольця. - заявл. 23.05.2016; опубл. 26.06.2017. - Бюл. № 12/2017.

\section{References}

1. Tsaryk NP. [Cultivated mushrooms in mushroom growing and medicine. One of the essays on the situation in Ukraine]. Kharchova nauka i tekhnolohiia 2013; 4(25): 1047. Ukrainian.

2. Butkevych TA, Siatynia ML, Popovych VP. [Determination of physical and pharmaco-technological properties of Flammulina velutipes biomass dry powder]. Farmatsevt. chasop. 2016;2: 11-5. Ukrainian.

3. Siatynia ML, Popovych VP, Butkevych TA, Bisko NA, Krupodorova TA, Koziko NO; Bohomolets National Medical University, assignee. Biologically active substance with immunomodulatory activity UA 117165 (Patent) 2017 Jun 26. Ukrainian.
4. Вибір раціональних допоміжних речовин для створення таблеток «Ангіолін» методом вологої грануляції / О. С. Бідненко, Л. І. Кучеренко, І. А. Мазур [та ін.] // Фармацевт. часоп. - № 2. - 2016. - С. 16-21.

5. Державна Фармакопея України: в 3 т. / Державне підприємство «Український науковий фрармакопейний центр якості лікарських засобів». - 2-е вид. - Харків : Державне підприємство «Український науковий фрармакопейний центр якості лікарських засобів», 2015. - Т. 1. -1128 c.

6. Математичне планування експерименту при проведені наукових досліджень в фрармації / [Грошовий Т. А., Марценюк В. П., Кучеренко Л. І. та ін.]; під ред. Т. А. Грошового. - Тернопіль : ТДМУ, Укрмедкнига, 2008. - 367 с.

4. Bidnenko OS, Kucherenko LI, Mazur IA, Moriak ZB. [Choice of rational excipients to create Angiolin" tablets by wet granualtion]. Farmatsevt chasop. 2016;2 : 16-21. Ukrainian.

5. State Pharmacopoeia of Ukraine: in 3 vol. / State Enterprise "Ukrainian Research Center expert pharmacopoeia quality medicines." - 2nd ed. - Kharkiv State Enterprise "Ukrainian Research Center expert pharmacopoeia drug quality," 2015; 1: 1128. Ukrainian.

6. Hroshovyi TA, Martseniuk VP, Kucherenko LI, Vronska LV, Hurieieva CM. Mathematical planning of experiment in pharmacy. [Математичне планування експерименту в орармації] Ternopil: Ternopil State Medical University; 2008. Ukrainian. 